\title{
Buoyancy and Stability Analysis of Ark'a Modulam Amphibious Foundation Model
}

\author{
Nomeritae $^{1, \mathrm{a})}$, Wijanarka ${ }^{2, \mathrm{~b})}$ \& Rudi Waluyo ${ }^{1, \mathrm{c})}$ \\ ${ }^{1)}$ Department of Civil Engineering, University of Palangka Raya, Palangka Raya, Indonesia. \\ ${ }^{2)}$ Department of Architecture, University of Palangka Raya, Palangka Raya, Indonesia. \\ Correspondent : ${ }^{a)}$ rita_busu@yahoo.co.id, ${ }^{b)}$ wijanark@gmail.com \& ${ }^{c)}$ rudiwaluyo3@gmail.com
}

\begin{abstract}
To solve problems of settlement in floodplain areas, research on the anti-flood foundation model is crucial. The anti-flood foundation model should be able to float during floods and to remain on land during non-flood conditions. This research focused on an amphibious foundation model named Ark'a Modulam. The reliability of Ark'a Modulam floating construction was analyzed for buoyancy and stability against vertical and horizontal loads. Two floating constructions were designed based on knockdown and rigid systems. Both systems were designed using iron pipes with 2.5 " and 4 " of diameter. No significant differences were found in the buoyancy forces of the 2 floating construction systems. The load that can be supported by 1 floating construction was a maximum of 0.954 ton and stable at a floating depth limit of $43.2 \mathrm{~cm}$. The stability of the floating construction should include the effect of vertical drive piles. The vertical and horizontal loads acting on the construction positioned inside Kahayan River during an extreme flood were also analyzed. During an extreme flood with 100 years of the return period, the construction of one vertical drive piles should able to support vertical forces equal to or larger than 7.50 ton
\end{abstract}

Keyword : infrastructure management, Ark'a modulam, amphibious foundation, buoyancy, flood

\section{INTRODUCTION}

The increasing number of impervious catchment area combined with natural factors such as the increasing rainfall depth has resulted in increasing discharge that has to be conveyed by the river. When the discharge exceeds the capacity of the river, water will overflow and flooding occurs in areas outside the river body. The area is known as floodplain which is created by sedimentation and is part of the river ecosystem (Powell \& Gabe, 2009).

Infrastructure built in a region has a strong correlation with externalities, such as geographical and environmental conditions. Thus, for areas susceptible to natural hazards, infrastructure life cycles such as policy, idea, planning, design, and construction of buildings (Suprayitno \& Soemitro, 2018) in this area are crucial. Early settlements of cities in Kalimantan were usually built on a floodplain. These settlements still exist and grow. Elevated house or stilt house construction is chosen as the area is susceptible to flood. However, as the magnitude of discharge increases, the flood depth also increases. Thus, building vertical construction in the form of a traditional elevated or stilt house on floodplain will not solve the problem for the longer term.

Therefore, it is necessary to find a model of houses so that the shape of the houses of stilt will not be submerged in the water when high floods occur. The key to solving the problem is finding a suitable and reliable amphibious foundation design. By studying and analyzing a 
number of floating and elevated designs, Ark'a Modulam was introduced, analyzed, and physically tested (Wijanarka \& Waluyo, 2017; Wijanarka, Waluyo, \& Nomeritae, 2019)).

This article is focused on reliability and total load that can be supported by Ark'a modulam. Buoyancy and stability analysis are presented by considering two environments for the model: (1) during an ideal condition and (2) during an extreme flood.

\section{RESEARCH METHODS}

\section{Previous Research on Ark'a Modulam}

This article is part of a 3 years research on an amphibious foundation. Ark'a Modulam amphibious construction model developed consists of 3 construction parts: 1) construction of vertical drive piles, 2) pier construction, and 3) floating construction (Wijanarka \& Waluyo, 2017).

In the first year of the research, several models of amphibious construction were compared (Figure 1). The model was basically developed with different designs of the floating construction. Four different designs named A-1, A-2, A-3, and A-4 were compared analytically.
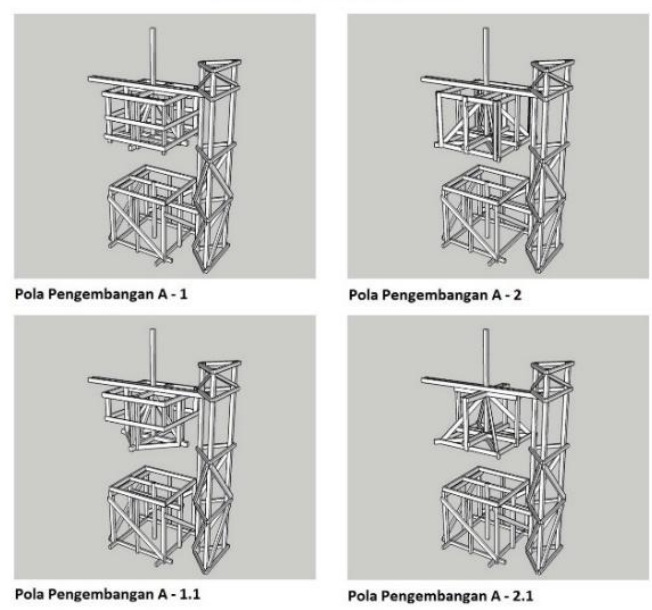

Figure 1. Model development of amphibious construction

(Source: (Wijanarka \& Waluyo, 2017)

Model A-21 was selected as it was more effective, efficient, and feasible to be tested compared to other models.

This model was further developed by comparing three different models of connection between floating construction and construction of vertical drive piles (Figure 2).

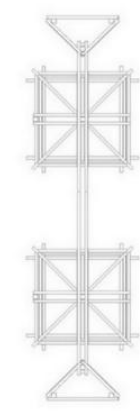

(a) Alt. 1

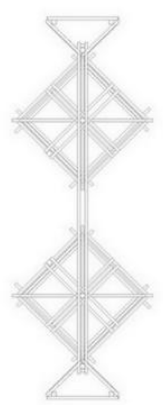

(b) Alt. 2

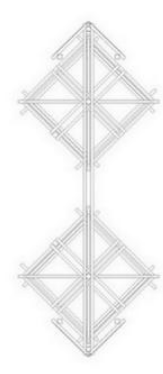

(c) Alt. 3

Figure 2. Three different models of connection between floating construction and vertical drive piles construction.

(Source: Wijanarka \& Waluyo, 2017) 
Model A-21 Alt. 3 was chosen as it binds the 3 parts of construction, thus it was more stable. Model Alt. 3 was then physically built and tested (Figure 3 ).

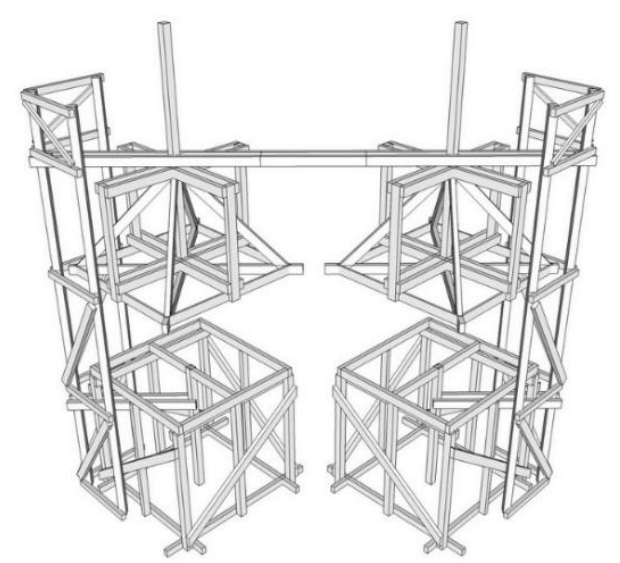

Figure 3. Physical built with model A-21 Alt3.

(Source: (Wijanarka \& Waluyo, 2017)

In the second year, the floating test and material design were conducted. The material used for the construction of the plugged-in poles was wood. The wood size was $8 / 8$ for the base construction, and 5/10 for the beam, and $5 / 5$ for the joists. For floating construction, the size was $8 / 8$ for main poles, $5 / 10$ for the beam, and $5 / 5$ for a frame beam, and 5/7 for the backing buoyant materials. For the vertical driving poles construction, the wood size was $8 / 8$ for the main poles, $5 / 7$ for the supporting poles, and 5/7 for the joists. The wood material was Meranti and Kruing trees. The connection construction among the wood used bolt and nails to attach to the joists. The floating material used was a plastic drum with a volume of 200 liters.

The floating test was carried out in a village at the floodplain in Palangka Raya located at Jl. Anoi Komplek Mendawai. Based on observation and interview with the residents, the flood depth at this location can reach up to 2 meters height. Therefore, the surrounding residential houses use stilts construction with $2.5 \mathrm{~m}-3 \mathrm{~m}$ height. From the results of the experiment, it was found that the weight of floating construction without four drums was $157 \mathrm{~kg}$. When the water level reached $98 \mathrm{~cm}, 78 \mathrm{~cm}$ of foundation construction height was submerged. However, the floating construction with $5 / 10$ wood base beams was not floated up. It began to float up when the water level reached $115 \mathrm{~cm}$.

\section{Buoyancy and Stability Analysis}

In this research, the reliability of Ark'a Modulam floating construction was analyzed for buoyancy and stability against vertical and horizontal loads.

Two types of floating construction built from iron pipes will be assembled: knockdown and rigid types. Both systems are designed to be built using iron pipes with 2.5 " and 4 " of diameter. In Figure 4, the floating construction was designed by using iron pipes with $6 \mathrm{~cm}$ and $10 \mathrm{~cm}$ of a diameter which are represented by diameter $2.5 "$ and $4 "$ of pipes available in the market, respectively. 


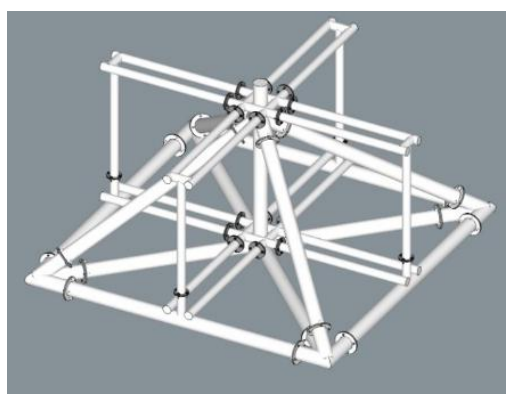

Figure 4. Sketch of design floating construction with a knockdown system built with iron pipes.

The floating construction was designed by referring to Figures 2 and 3. The bottom shape of the structure was a square with $228 \mathrm{~cm}$ of width and $116 \mathrm{~cm}$ of height. In the knockdown system, the connections between iron pipes were joint with bolts and coated with rubber. The size of the bolts used in the physical model will be adjusted during the assembly of the physical model.

Two environments were designed to test the buoyancy and stability of the floating construction. The first environment was an ideal condition where the floating construction was in a still condition and the only vertical load was forced unto the surface (no horizontal forces). In the second environment, vertical and horizontal forces were assigned unto the floating construction surfaces. This condition was created by assuming that the construction was submerged and horizontal forces were induced by inflow coming from upstream. Inflow forced into the model was calculated by using design velocity. The design velocity was analyzed based on a magnitude of design discharge in an extreme condition. Thus, a hydrological and hydraulic analysis was conducted in this research.

A series of annual maximum rainfall data were analyzed to predict the rainfall depth for a certain return period. Then, the design discharge was estimated using a synthetic hydrograph method.

The value of the design discharge was used as an inflow in hydraulics analysis. To identify the flow profile, a one-dimensional model of permanent and non-permanent flow (steady and steady one-dimensional flow model) known as HEC-RAS (Hydraulic Engineering Center - River Analyses) was used.

Assuming that the construction is in a still condition (Figure 5), the buoyancy force $\left(\mathrm{F}_{\mathrm{G}}\right)$ acting on the floating construction is calculated as

$$
\mathrm{F}_{\mathrm{G}}=\gamma_{\mathrm{C}} \mathrm{BH}
$$

where $\mathrm{c}$ denotes construction, $\gamma$ is the specific weight, $\mathrm{B}$ and $\mathrm{H}$ are the construction width and depth, respectively. At a stable condition, the lift force $\left(F_{L}\right)$ is equal to the buoyancy force $\left(F_{G}\right)$.

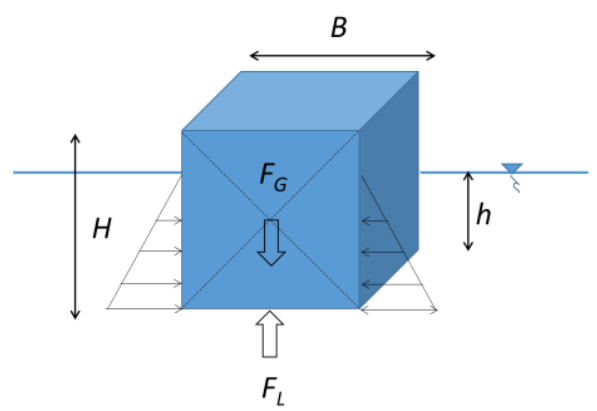

Figure 5. Forces acting on the floating construction during a still condition. 

Figure 6.

For a submerged floating construction, forces acting on the model are as depicted in

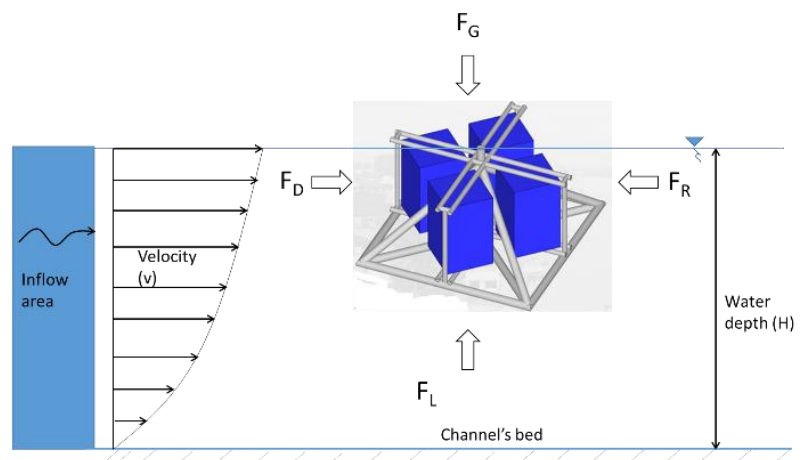

Figure 6. Floating construction with forces acting on the model in a submerged condition.

Submerged weight of floating construction $\left(\mathrm{F}_{\mathrm{G}}\right)$ can be calculated as (Junqiang, Teo, Lin, \& Falconer, 2011):

$$
\mathrm{F}_{\mathrm{G}}=\left(\gamma_{\mathrm{c}}-\gamma_{\mathrm{w}}\right) \mathrm{V}_{\mathrm{c}}=\left(\rho_{\mathrm{c}}-\rho_{\mathrm{w}}\right) \mathrm{gV}_{\mathrm{c}}
$$

where $\mathrm{c}$ and $\mathrm{w}$ denote construction and water, respectively, $\rho$ corresponding to density, $\mathrm{g}$ is the gravitational acceleration, and $\mathrm{V}$ represents volume.

The pressure difference between flow velocities at the top and the bottom of the floating construction results in a lift force $\left(\mathrm{F}_{\mathrm{L}}\right)$ and can be expressed as (Junqiang, Teo, Lin, \& Falconer, 2011) :

$$
\mathrm{F}_{\mathrm{L}}=\mathrm{C}_{\mathrm{L}} \mathrm{A}_{\mathrm{L}} \gamma_{\mathrm{w}} \frac{\mathrm{u}_{\mathrm{b}}^{2}}{2 \mathrm{~g}}
$$

in which $u_{b}$ is the representative velocity near the channel's bed; $C_{L}$ is lift coefficient, and $A_{L}$ is the acting area by the lift force. The value of $C_{L}$ is based on angles of flow attack (Figure 7).

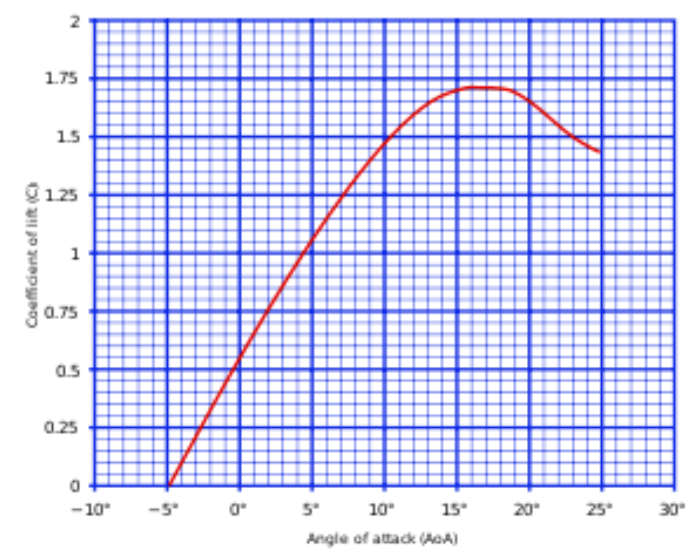

Figure 7. Predicted values of $C_{L}$ based on the angle of attack.

(Source: Abbot \& van Doenhoeff (1959)

As water passes through floating construction, a frictional surface force is exerted on its surface. If the flow is relatively high, a pressure difference between the front and the back of the construction causes a resistance force known as the drag force. The drag force acting on a side of the construction is given in the following general form (Junqiang, Teo, Lin, \& Falconer, 2011):

$$
F_{D}=C_{D} A_{D} \gamma_{w} \frac{u_{b}^{2}}{2 g}
$$


in which $C_{D}$ is the drag coefficient; and $A_{D}$ is the submerged area projected to the flow. The drag coefficient is defined based on the shape of the construction as described in Table 1 (McCormick \& Barnes, 1979).

Table 1. Measured Drag Coefficient $\left(\mathrm{C}_{\mathrm{D}}\right)$

\begin{tabular}{lc}
\hline \multicolumn{1}{c}{ Shape } & Drag Coefficient $\left(\mathbf{C}_{\mathbf{D}}\right)$ \\
\hline Sphere & 0.47 \\
\hline Half-sphere & 0.42 \\
\hline Cone & 0.5 \\
\hline Cube & 1.05 \\
\hline Angled Cube & 0.8 \\
\hline Long Cylinder & 0.82 \\
\hline Short Cylinder & 1.15 \\
\hline Streamlined Body & 0.04 \\
\hline Streamlined Half-body & 0.09 \\
\hline (Source: McCormick \& Barnes (1979)) &
\end{tabular}

Since the frictional force $\left(\mathrm{F}_{\mathrm{R}}\right)$ is replaced with the force of vertical drive piles, then it assumed that $F_{R}$ is equal to $F_{D}$, so the whole construction is stable.

\section{DATA COLLECTION}

Data analyzed in this research was mainly using secondary data. Thus, this research used data available in the literature and based on the final report on Ark'a Modulam's project.

\section{RESEARCH ANALYSIS}

\section{Buoyancy and Stability of Ark'a Modulam in a Still Condition.}

The weight of the floating constructions with 4 (four) plastic drums was calculated by assuming that the specific weight $(\gamma)$ of the iron pipes constructed is $7850 \mathrm{~kg} / \mathrm{m}^{3}$. The total weight of the floating construction with iron pipes for knockdown and the rigid system was 0.175 ton and 0.162 ton, respectively. The total weight of 4 plastic drums with $936 \mathrm{~mm}$ long and $581 \mathrm{~mm}$ wide was 0.7784 ton. The total weight load of each system of floating construction with 4 plastic drums was described in Table 2.

Table 2. Total weight and floating depth limit of 2 types of floating construction

\begin{tabular}{lcc}
\hline $\begin{array}{c}\text { Types of floating } \\
\text { construction }\end{array}$ & Total weight load (ton) & $\begin{array}{c}\text { Floating depth } \\
\text { limit (m) }\end{array}$ \\
\hline Knockdown & 0.954 & 0.432 \\
\hline Rigid & 0.941 & 0.426 \\
\hline
\end{tabular}

Based on previous research (Wijanarka \& Waluyo, 2017), the maximum load that can be supported by wooden material was 0.701 tons. Thus, compared to floating construction made from wooden material, construction made from iron was able to support heavier construction.

However, the maximum load and floating depth limit that can be supported by both material were calculated by considering floating construction only. The other two constructions (vertical drive piles and pier constructions) were not considered. 


\section{Stability Analysis of Ark'a Modulam During An Extreme Flood}

The amphibious construction model is aimed to be tested and built in a floodplain. In this analysis, the construction was assumed to be built in a section of Kahayan River's floodplain and experienced the same magnitude of an extreme flood occurrence as it was in the river (Figure 8).

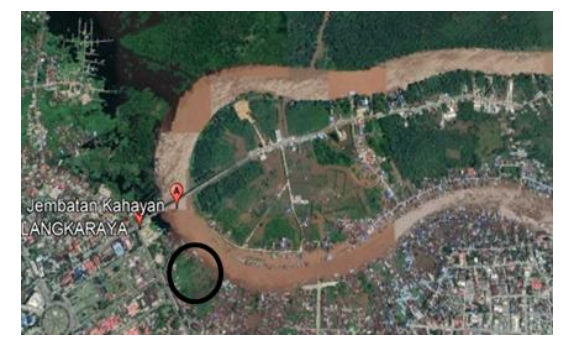

Figure 8. Kahayan River at Central Kalimantan with Jembatan Kahayan and assumption of the location where the amphibious foundation was built (circled).

(Source: Google Earth)

To calculate the conveyance of a river, a geodetic measurement over the river is required. The geodetic measurement in the Kahayan river section was adapted (Nomeritae, Yupi, \& Afentina, 2018).

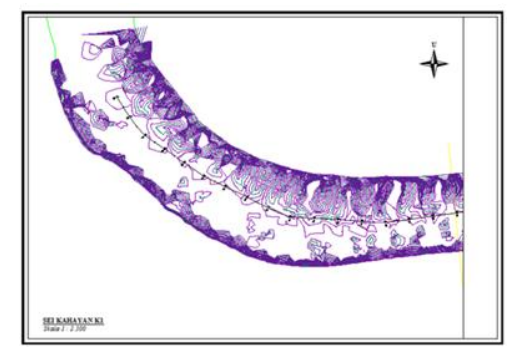

Figure 9. Geodetic river measurement results (Source: Nomeritae, Yupi, \& Afentina (2018))

Velocity and water depth around the channel's section was analyzed by using HEC-RAS. HEC-RAS is an application program to model the flow in the river (River Analysis System (RAS)), made by the Hydraulic Engineering Center (HEC) which is a division within the Institute for Water Resources (IWR), under the US Army Corps of Engineers (USACE ).

\section{Hydrological Analysis}

The maximum daily rainfall data was obtained from 2 (two) rainfall stations in Palangka Raya named Bereng Bengkel and Palangka Raya stations. The results of the frequency analysis produced design rainfall with a 100-year return period (Table 3). Based on goodness of fit and Smirnov-Kolmogorov tests, normal distribution with $\left(\mathrm{X}_{100}\right)$ of $151.668 \mathrm{~mm}$ was the most suitable distribution for the analysis.

Table 3. Design rainfall for several return periods according to its distribution

\begin{tabular}{ccccccccc}
\hline \multirow{2}{*}{$\begin{array}{c}\text { Return Period } \\
(\boldsymbol{Y}) \text { Years }\end{array}$} & \multicolumn{2}{c}{ Normal } & \multicolumn{2}{c}{ Log-Normal } & \multicolumn{2}{c}{ Gumbel } & \multicolumn{2}{c}{ Log Pearson III } \\
\cline { 2 - 9 } & $\boldsymbol{X}_{\boldsymbol{Y}}$ & $\boldsymbol{K}_{\boldsymbol{Y}}$ & $\boldsymbol{X}_{\boldsymbol{Y}}$ & $\boldsymbol{K}_{\boldsymbol{Y}}$ & $\boldsymbol{X}_{\boldsymbol{Y}}$ & $\boldsymbol{K}_{\boldsymbol{Y}}$ & $\boldsymbol{X}_{\boldsymbol{Y}}$ & $\boldsymbol{K}_{\boldsymbol{Y}}$ \\
\hline 5 & 128.342 & 0.842 & 128.17 & 0.831 & 126.423 & 0.719 & 128.297 & 0.849 \\
\hline 10 & 135.254 & 1.282 & 136.196 & 1.342 & 135.615 & 1.305 & 135.819 & 1.261 \\
\hline 50 & 147.385 & 2.054 & 151.519 & 2.317 & 155.846 & 2.592 & 149.569 & 1.96 \\
\hline 100 & 151.668 & 2.326 & 157.331 & 2.687 & 164.398 & 3.137 & 154.583 & 2.199 \\
\hline
\end{tabular}


Since the measured discharge data is not available, the upstream boundary condition used a series of discharge data obtained from unit hydrograph analysis based on a 100-year rainfall design. The rainfall distribution model used was the distribution of high rainfall plans in a series of $\mathrm{n}$ time intervals with a duration of $\Delta \mathrm{t}$ during time $\mathrm{t}$. The method used was the Alternating Block Method (ABM) hyetograph method (Figure 10). Next, the Synthesis Unit Hydrograph was analyzed using the Nakayasu method (Figure 11).

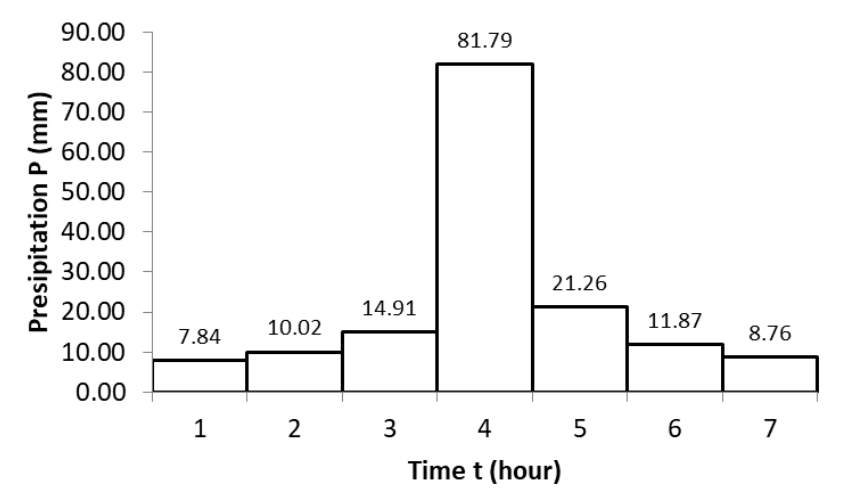

Figure 10. ABM Hyetograph

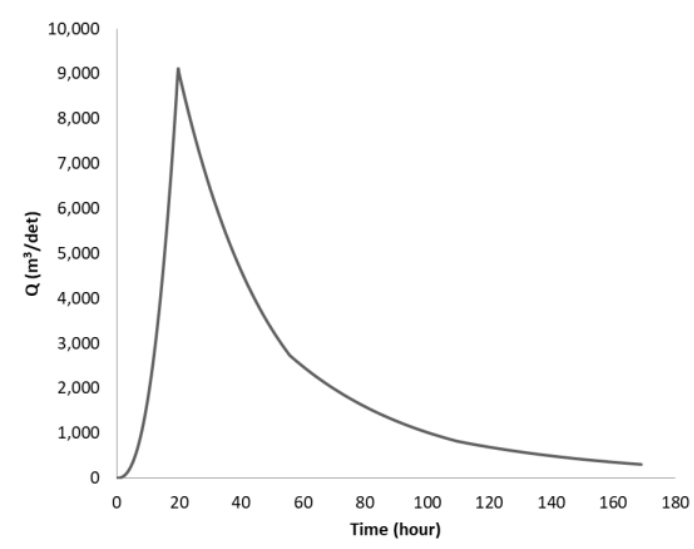

Figure 11. Runoff hydrograph using Nakayasu method.

The geometry of the river's section was modeled with several river stations. The upstream cross-section was at Station 800 while Station 0 was the most downstream cross-section. The Kahayan Bridge was located at station 479. The Kahayan river scheme in the HEC-RAS program can be seen in Figure 12. The river reach was drawn as a straight line different from Figure 9. The river reach drawing does not influence the result.

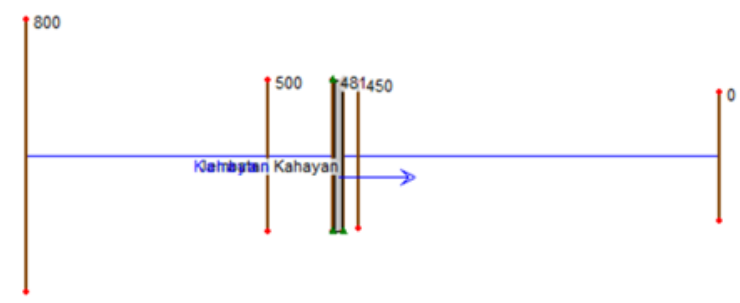

Figure 12. Geometric data of a section of Kahayan River. 
To model steady flow analysis in HEC-RAS, the maximum discharge with 100 years return period $\left(\mathrm{Q}_{100}=9,103.82 \mathrm{~m}^{3} / \mathrm{s}\right)$ was used as an upstream boundary condition. Normal depth was chosen as the downstream boundary condition with friction slope 0.00016 .

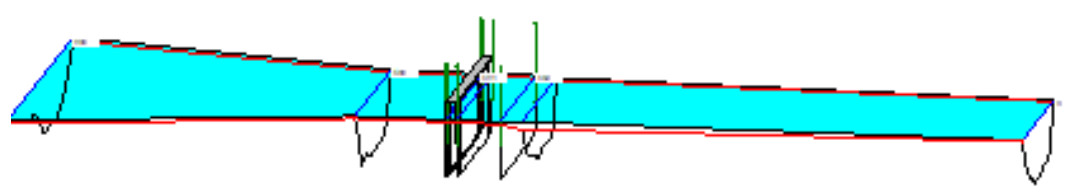

Figure 13. Simulation result with $X Y Z$ perspective

An example result of the simulation for the upstream cross-section is shown in Figure 14, while the flow characteristic of each cross-section is shown in Table 4.

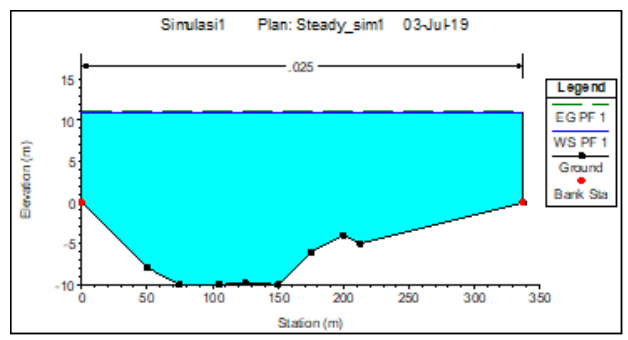

Figure 14. Water depth and top width of the cross-section at river station 800 .

Table 4. Flow characteristic inside channel with $Q=9,103.82 \mathrm{~m}^{3} / \mathrm{s}$ and slope 0.00016 .

\begin{tabular}{cccccc}
\hline \multirow{2}{*}{$\begin{array}{c}\text { River } \\
\text { Sta }\end{array}$} & $\begin{array}{c}\text { Q Total } \\
\text { Min }\end{array}$ & $\begin{array}{c}\text { Water } \\
\text { depth }\end{array}$ & $\begin{array}{c}\text { Vel } \\
\text { Chnl }\end{array}$ & $\begin{array}{c}\text { Flow } \\
\text { Area }\end{array}$ & $\begin{array}{c}\text { Top } \\
\text { Width }\end{array}$ \\
\cline { 2 - 6 } & $\mathbf{( \mathbf { m } ^ { 3 } / \mathbf { s } )}$ & $\mathbf{( m )}$ & $\mathbf{( m / s )}$ & $\left.\mathbf{( m}^{\mathbf{2}}\right)$ & $\mathbf{( m )}$ \\
\hline 800 & 9103.82 & 10.89 & 1.64 & 5540.54 & 337.5 \\
\hline 500 & 9103.82 & 10.63 & 2.63 & 3462.22 & 187.5 \\
\hline 481 & 9103.82 & 10.62 & 2.66 & 3427.3 & 187.5 \\
\hline 479 & Bridge & & & & \\
\hline 469 & 9103.82 & 10.6 & 2.67 & 3403.42 & 187.5 \\
\hline 450 & 9103.82 & 10.55 & 2.82 & 3222.7 & 180 \\
\hline 0 & 9103.82 & 10.37 & 3.17 & 2874.29 & 160 \\
\hline \multicolumn{7}{c}{ Average } & 10.61 & 2.60 & & \\
\hline \multicolumn{7}{c}{}
\end{tabular}

\section{Vertical and Horizontal Loads}

The average velocity along the channel was predicted to be around $2.60 \mathrm{~m} / \mathrm{s}$ and the average water depth was $10.61 \mathrm{~m}$. In this research, the calculated average velocity value was assumed to be equal to the velocity near the channel's bed $\left(u_{b}\right)$. Thus, the values of $F_{L}, F_{G}, F_{D}$, and $F_{R}$ can be predicted.

The calculation of the forces acting on the floating construction was as follows:

$\begin{array}{lll}\gamma_{\mathrm{c}} & =7.85 & \text { ton } / \mathrm{m}^{3} \\ \gamma_{\mathrm{w}} & =1 & \text { ton } / \mathrm{m}^{3} \\ \mathrm{~V} & =0.12 & \mathrm{~m}^{3} \\ \mathrm{~F}_{\mathrm{G}} & =0.83 & \text { ton } \\ \mathrm{C}_{\mathrm{L}} & =0.55 & \\ \mathrm{~A}_{\mathrm{L}} & =5.20 & \mathrm{~m}^{2} \\ \gamma_{\mathrm{c}} & =7.85 & \text { ton } / \mathrm{m}^{3} \\ \mathrm{u}_{\mathrm{b}} & =2.60 & \mathrm{~m} / \mathrm{s}\end{array}$




$\begin{array}{lll}\mathrm{g} & =9.81 & \mathrm{~m} / \mathrm{s}^{2} \\ \mathrm{~F}_{\mathrm{L}} & =7.72 & \text { ton } \\ \mathrm{C}_{\mathrm{D}} & =1.05 & \\ \mathrm{~A}_{\mathrm{D}} & =2.64 & \mathrm{~m}^{2} \\ \gamma_{\mathrm{c}} & =7.85 & \text { ton } / \mathrm{m}^{3} \\ \mathrm{u}_{\mathrm{b}} & =2.60 & \mathrm{~m} / \mathrm{s} \\ \mathrm{g} & =9.81 & \mathrm{~m} / \mathrm{s}^{2} \\ \mathrm{~F}_{\mathrm{D}} & =7.50 & \text { Ton }\end{array}$

To stabilize the drag force, the value of $F_{R}$ has to be designed equal to or larger than 7.50 ton. Thus, the construction of one vertical drive piles should able to support vertical forces equal to or larger than 7.50 ton.

\section{CONCLUSION}

Ark'a modulam as an amphibious foundation is a reliable construction of which is able to support vertical and horizontal forces act on its construction. No significant difference in total load was found between floating construction with knockdown and rigid systems. However, compared to floating construction made from wooden material, construction made from iron is able to support heavier construction. During extreme flood conditions, the construction experiences a large magnitude of forces and considerable water depth.

ACKNOWLEDGMENT. This article is part of a research project funded by Ristekdikti through the Institute of Research and Community Service of the University of Palangka Raya. This paper was selected from WUICACE 22019 - Warmadewwa University International Conference on Architecture and Civil Engineering, organized by the Faculty of Engineering, Warmadewa University.

\section{BIBLIOGRAPHY}

Abbot, I.H., \& Von Doenhoeff, A.E. (1959). Theory of Wing sections. Including Airfoil Data. Dover Publications. Inc. New York.

Junqiang, X., Teo, F. Y., Lin, B., \& Falconer, R.A. (2011). "Formula of incipient velocity for flooded vehicles". Nat Hazards. Vol. 58, pp. 1-14.

McCormick, \& Barnes, W. (1979). Aerodynamics, Aeronautics, and Flight Mechanics. John Wiley \& Sons, Inc. New York.

Nomeritae, Yupi, H. M., \& Afentina. (2018). "Rekayasa Hidraulik untuk Pengendalian Erosi dan Sedimentasi Ruas Sungai Kahayan Berstruktur Membentang Sungai". Jurnal Teknika. Vol. 2, No. 1, pp. 1-12.

Powell, \& Gabe, W. (2009). Identifying Land Use/Land Cover (LULC) Using National Agriculture Imagery Program (NAIP) Data as a Hydrologic Model Input for Local Flood Plain Management. Texas State University. Texas.

Suprayitno, H., \& Soemitro, R.A.A. (2018). "Preliminary Reflexion on Basic Principle of Infrastructure Asset Management". Jurnal Manajemen Aset Infrastruktur \& Fasilitas, Vol. 2, No. 1, pp. 1-9.

Waluyo, R., Wijanarka, \& Nomeritae (2019). "Estimasi Biaya Konstruksi Pondasi Anti Banjir". Prosiding SNSRT. Fakultas Sains dan Teknologi, Universitas Pelita Harapan. Tangerang.

Wijanarka \& Waluyo, R. (2017). "The Innovation of Flood Resistant Foundation: Development Study And Reliability of Ark'a Modulam (Module of Amphibious), With Various Floating Materials Through The Model Physical Test". International Conference on Architecture 2017 (ICRP-AVAN), pp. 106-111. Unsyiah. Banda Aceh.

Wijanarka, Waluyo, R. \& Nomeritae. (2019). "Experimentation for Development for Ark'a Modulam Foundation as an Alternative to Create Amphibious Architecture in the Urban Floodplain in Kalimantan". Indian Journal of Science and Technology. Vol. 12, No. 19, pp. 1-15. 